\title{
Perbedaan Kadar HSP90 pada Preeklamsi Berat dengan Kehamilan Normal
}

\author{
Soetrisno_Supriyadi Hari Respati, Sri Sulistyowati, Yusuf Antoni \\ Departemen Obstetri dan Ginekologi Fakultas Kedokteran Universitas Sebelas Maret \\ Rumah Sakit Umum Daerah Dr. Moewardi Surakarta
}

\begin{abstract}
Abstrak
Preeklamsi berat merupakan penyebab kedua terbesar kematian ibu di seluruh dunia. Radikal bebas menstimulir kadar heat shock protein 90 (HSP90), diduga menentukan terjadinya preeklamsi berat. HSP90 merupakan protein penting untuk membantu pembentukan dan pemeliharaan protein lain serta untuk memacu kelangsungan hidup sel setelah terjadi berbagai macam keadaan patologis (fungsi chaperone). Fungsi chaperone merupakan faktor kunci adaptasi terhadap stres endogen di beberapa jaringan. Dengan mengetahui kadar HSP90, sebagai deteksi dini preeklamsi berat, maka dapat dilakukan upaya pencegahan dan penanganan secara dini. Penelitian ini bertujuan membuktikan bahwa kadar HSP90 pada kehamilan dengan preeklamsi berat lebih tinggi dibanding dengan kehamilan normal. Metode penelitian studi kuantitatif observasional pendekatan potong lintang dengan pendekatan uji laboratoris kadar HSP90. Studi dilakukan bulan September-November 2013 di Bagian Obstetri dan Ginekologi RS Dr. Moewardi Surakarta dan Prodia Jakarta. Subjek 30 pasien terdiri atas 15 pasien hamil dengan preeklamsi berat dan 15 pasien normal. Dilakukan pemeriksaan kadar HSP90 serum dengan metode enzymelinked immunosorbent assay (ELISA). Data dianalisis menggunakan uji-t dengan SPSS versi 17.00 for Windows. Didapatkan kadar HSP90 rata-rata kelompok preeklamsi berat sebesar 131,91 26,66 , sedangkan kelompok kehamilan normal 80,28 $\pm 13,39$ dengan $\mathrm{p}=0,00(\mathrm{p}<0,05)$. Kadar HSP90 serum preeklamsi berat lebih tinggi dibanding dengan kehamilan normal karena pada preeklamsi berat terjadi stres oksidatif. [MKB. 2015;47(2):65-8]
\end{abstract}

Kata kunci: HSP90, preeklamsi berat, radikal bebas

\section{The Difference of HSP 90 Level between Severe Pre-Eclampsia and Normal Pregnancy}

\begin{abstract}
s
Severe pre-eclampsia is the second highest cause of maternal mortality. Free radicals that stimulate heat shock protein 90 (HSP 90) are believed to determine severe pre-eclampsia. HSP90 is an important protein that helps the establishment and maintenance of other proteins. It also increases the life time of cells after various pathological conditions (chaperone function). The chaperone function is the adaptation key factor to endogenous stress in tissues. By recognizing HSP90 level in early detection of severe pre-eclampsia, prevention and management can be started early. This study aimed to prove that the HSP90 level in pregnancy with severe pre-eclampsia is higher than normal pregnancy. This was a quantitative study using cross sectional approach by testing the HSP90 level. The study was conducted during the period of September to November 2013, at the Obstetrics and Gynecological Unit, Moewardi Hospital Surakarta and Prodia Laboratory Jakarta. The number of subjects was 30 patients, consisting of 15 normal pregnant mothers and 15 pregnant mothers with pre-eclampsia. The calculation of serum HSP90 level was conducted using enzyme-linked immunosorbent assay (ELISA). Data were analyzed using t-test using SPSS for Windows version 17 for Windows. The mean of HSP90 in the severe pre-eclampsia group was $131.91 \pm 26.66$ while the mean in the normal pregnancy group was $80.28 \pm 13.39$ with $\mathrm{p}=0.00(\mathrm{p}<0.05)$. Level of HSP90 serum in severe pre-eclampsia is higher than in normal pregnancy, due to the occurrence of oxidative stress in severe pre-eclampsia [MKB. 2015;47(2):65-8]
\end{abstract}

Key words: Free radicals, HSP90, severe pre-eclampsia

Korespondensi: Dr. Soetrisno, dr., Sp.OG(K), Departemen Obstetri dan Ginekologi Fakultas Kedokteran Universitas Sebelas Maret/RSUD Dr. Moewardi Surakarta, Jalan Kolonel Sutarto No. 132, Surakarta, Jawa Tengah, mobile 0816672564, e-mail soetrisno_spogk@yahoo.com 


\section{Pendahuluan}

Preeklamsiberatmerupakangangguankehamilan ditandai dengan hipertensi dan proteinuria yang akan membaik setelah persalinan. ${ }^{1}$ Frekuensi terjadinya preeklamsi berat adalah $5-7 \%$ dari semua wanita hamil dan merupakan penyebab kedua terbesar kematian ibu di seluruh dunia. ${ }^{2}$ Di Amerika Latin dan negara Karibia angka kematian karena preeklamsi berat lebih besar, yaitu $25,7 \%{ }^{3}$ Angka kejadian preeklamsi berat di Indonesia 3-10\% memberikan kontribusi kematian ibu sebesar 39,5\% pada tahun 2001 dan meningkat tajam menjadi $55,56 \%$ pada tahun 2002. Kematian biasanya oleh eklampsi atau komplikasi preeklamsi berat. Di RSUD Dr. Moewardi Surakarta kematian ibu hamil yang disebabkan oleh preeklamsi berat adalah 67,6\% dari 1.956 persalinan pada tahun 2008. Kehamilan normal, tubuh akan memproduksi partikel kecil yang memiliki tenaga besar berupa atom atau molekul dengan elektron bebas yang disebut sebagai radikal bebas. Radikal bebas ini dipergunakan untuk menghasilkan tenaga beberapa fungsi fisiologis seperti kemampuan untuk membunuh virus dan juga bakteri. Namun, apabila jumlahnya terlalu banyak misalnya yang terjadi akibat pengaruh faktor lingkungan maka zat ini dapat berakibat merusak jaringan normal termasuk sistem vaskular. Dalam hal ini akan timbul gangguan produksi DNA, lapisan lipid pada dinding sel endotel pada sistem vaskular sehingga memengaruhi fungsi pembuluh darah. Tampaknya hal ini berhubungan erat dengan kejadian preeklamsi berat. ${ }^{4}$

Dilaporkan bahwa kejadian preeklamsi berat berhubungan erat dengan faktor lingkungan, yaitu terdapat beberapa logam (misalnya besi, tembaga), asap rokok, polusi udara, obat, bahan beracun, makanan dalam kemasan, bahan aditif dan juga sinar ultraviolet dari matahari maupun radiasi, serta olah raga yang berlebihan. Hal ini semua karena pada faktor tersebut dijumpai banyak radikal bebas yang sangat menentukan terjadinya preeklamsi berat. ${ }^{5,6,7}$

Hubungan antara radikal bebas (faktor lingkungan) dengan terjadinya preeklamsi berat sampai saat ini belum dapat dijelaskan, khususnya secara biomolekuler. Pada studi ini akan dilakukan penelitian mengenai hubungan peningkatan radikal bebas tersebut khususnya yang berhubungan dengan peran HSP90.

Pada wanita hamil dengan faktor lingkungan yang berpotensi menimbulkan radikal bebas yang akan berakibat antioksidan itu rendah. Ketidakseimbangan di dalam suatu mekanisme pengaturan kompensasi antioksidan dengan radikal bebas akan mengakibatkan kejadian kondisi yang disebut stres oksidatif. Hal ini akan berdampak pada peningkatan hypoxia-inducible factor (HIF) sebagai akibat kondisi hipoksia pada vaskular, yang selanjutnya HIF ini akan merangsang transkripsi heat shock factor (HSF). ${ }^{8}$

Dilaporkan bahwa transkripsi HSF sangat diperlukan untuk induksi HSP selama hipoksia dan reoksigenasi khususnya kadar HSP90. HSP90 merupakan protein penting untuk membantu pembentukan dan pemeliharaan protein lain serta untuk memacu kelangsungan hidup selsel setelah terjadi berbagai macam keadaan patologis (fungsi chaperone). Fungsi chaperone merupakan faktor kunci untuk adaptasi terhadap stres endogen di beberapa jaringan. ${ }^{9}$

Dilaporkan bahwa kadar protein (HSP90) sangat penting sebab jika terlalu sedikit atau banyak maka kadar HSP90 dapat menyebabkan keadaan patologis yang berupa pertumbuhan tidak normal, malformasi perkembangan, dan kematian sel. Peningkatan kadar HSP90 yang masih di dalam batas nilai ambang merupakan sarana penting untuk perlindungan seluler selama stres patologis (distress). ${ }^{5-7}$

HSP adalah suatu protein yang mempunyai efek serta memengaruhi proses transkripsi yang menghasilkan sitokin proinflamasi seperti IL$1 \beta$ dan TNF- $\alpha$. Endotel pembuluh darah apabila menerima rangsangan dari sitokin proinflamasi (IL-1 $\beta$ dan TNF- $\alpha$ ) akan mengeluarkan bahan adhesi molekul monosit salah satunya adalah VCAM-1. Terdapatnya VCAM-1 pada monosit akan mengeluarkan enzim MMP-9 yang dapat merusak kolagen tipe 4 dan vaskular. Kerusakan vaskular akan menyebabkan disfungsi endotel yang merupakan bagian dari reaksi inflamasi maternal yang mampu menimbulkan iskemik arteria spiralis yang selanjutnya akan berakibat penurunan perfusi plasenta dengan dampak muncul sindrom klinis preeklamsi. ${ }^{11-13}$ Pada studi ini akan diteliti secara biomolekuler khususnya hubungan kadar protein HSP90 dengan kejadian preeklamsi berat.

\section{Metode}

Studi observasional analitik mempergunakan pendekatan rancangan potong lintang untuk meneliti perbedaan kadar protein HSP90 antara preeklamsi berat dan kehamilan normal. Studi dilakukan periode September-November 2013 di Bagian Obstetri dan Ginekologi Rumah Sakit Dr. Moewardi Surakarta dan Prodia Jakarta. 
Proposal penelitian dimintakan persetujuan komisi etik dan telah memperoleh/dinyatakan memenuhi aspek etika penelitian yang dapat dipertanggungjawabkan. Jumlah subjek yang diteliti adalah 30 pasien, terdiri atas 15 pasien hamil dengan preeklamsi berat dan 15 pasien hamil normal.

Kriteria inklusi penelitian ini yaitu usia 2025 tahun, usia kehamilan 37-40 minggu, janin tunggal hidup. Kriteria eksklusi ibu hamil dengan penyakitkronik: diabetes melitus, kelainan ginjal, jantung, hipertensi kronik, kehamilan kembar, ibu hamil dengan ketuban pecah dini, infeksi intrauterin, janin dengan kelainan kongenital, serta kelainan plasenta (hemangioma plasenta dan plasenta previa).

Subjek yang memenuhi kriteria inklusi dan tidak termasuk eksklusi dilakukan pemeriksaan fisis dan ultrasonography (USG) untuk penegakan diagnosis, kemudian dilakukan pemeriksaan kadar protein HSP90 serum dengan metode enzyme-linked immune-sorbent assay (ELISA). Data yang diperoleh kemudian dianalisis dengan menggunakan uji-t tidak berpasangan.

\section{Hasil}

Dari hasil pengambilan data setelah dilakukan analisis menggunakan uji-t tidak berpasangan didapatkan hasil sebagai berikut. Dari hasil analisis data menggunakan uji statistik $t$ tidak berpasangan setelah dilakukan uji normalitas dan homogenitas data dengan Uji KolmogorovSmirnov dan Lavene's, kadar HSP90 dalam serum kehamilan dengan preeklamsi berat lebih tinggi secara signifikan dibanding dengan kehamilan normal $(\mathrm{p}<0,05)$.

\section{Tabel Analisis Data Menggunakan Uji-t tidak Berpasangan Perbedaan Kadar HSP90 antara Kehamilan Preeklamsi Berat dan Normal}

\begin{tabular}{lccc}
\hline Kelompok & $\begin{array}{c}\text { Besar } \\
\text { Sampel } \\
\text { (n) }\end{array}$ & $\begin{array}{c}\text { Kadar Hsp- } \\
\text { 90 Rata-rata } \\
\text { (ng/mL) }\end{array}$ & $\begin{array}{c}\text { Nilai } \\
\mathbf{p}\end{array}$ \\
\hline Normal & 15 & $80,28 \pm 13,39$ & \\
$\begin{array}{l}\text { Preeklamsi } \\
\text { berat }\end{array}$ & 15 & $131,91 \pm 26,66$ & 0,00 \\
\hline
\end{tabular}

\section{Pembahasan}

Dari hasil penelitian ini didapatkan kadar HSP90 rata-rata serum kehamilan preeklamsi berat lebih tinggi dibanding dengan kehamilan normal $(p<0,05)$. Perbedaan lebih tinggi pada penelitian ini karena didapatkan faktor risiko pada ibu hamil dengan preeklamsi berat.

Soetrisno $^{6}$ mengemukakan bahwa kejadian preeklamsi berat berhubungan erat dengan faktor lingkungan, yaitu terdapatnya beberapa logam (misalnya besi, tembaga), asap rokok, polusi udara, obat, bahan beracun, makanan dalam kemasan, bahan adiktif dan juga sinar ultraviolet dari matahari maupun radiasi, serta olah raga yang berlebihan.

Pada wanita hamil dengan faktor lingkungan mempunyai potensi menimbulkan radikal bebas dan akan berakibat pada rendahnya antioksidan. Ketidakseimbangan di dalam suatu mekanisme pengaturan kompensasi antioksidan dengan radikal bebas juga akan menimbulkan kejadian kondisi yang disebut stres oksidatif. ${ }^{8}$

Stres yang dibangun ini yaitu sebagai faktor stimulasi transkripsi hypoxia-inducible factor (HIF) dalam sel endotel dan HIF diperlukan untuk sintesis heat shock protein 90 (HSP90) melalui aktivasi heat shock factor (HSF). HSP90 berfungsi melindungi protein dalam sel tersebut. Selain itu, juga mempunyai efek memengaruhi proses transkripsi yang menghasilkan sitokin proinflamasi seperti interleukin-1 $\beta$ (IL-1 $\beta$ ) dan tumor necrosis factor- $\alpha$ (TNF- $\alpha$ ).

Endotel pembuluh darah apabila menerima rangsangan dari sitokin proinflamasi IL-1 $\beta$ dan TNF- $\alpha$ dapat merusak kolagen tipe 4 dan vaskular. Kerusakan vaskular akan menyebabkan disfungsi endotel. Akibat gangguan ini sel trofoblas akan mengalami malformasi sehingga inadekuat dalam menginvasi arteri spiralis. Akibat yang ditimbulkan yaitu terjadi kegagalan remodeling arteri spiralis. Arteri spiralis yang seharusnya berdinding tebal dan berliku-liku menjadi pembuluh sinusoid lemah, iskemik, trombosis, dengan pertahanan yang rendah. Malformasi arteri spiralis ini dapat menyebabkan perfusi plasenta terganggu sehingga lebih lanjut akan menimbulkan keadaan hipoksia plasenta dan pada akhirnya plasenta mengalami keadaan iskemik. Keadaan hipoksia plasenta juga dapat memacu sekresi sitokin dan zat yang lain. Akibat dari kesemuanya akan menimbulkan gejala dan tanda preeklamsi berat. ${ }^{8}$

Dilaporkan bahwa kadar HSP90 serum yang lebih tinggi juga dapat dijumpai pada pasien preeklamsi berat dengan sindrom hemolisis, 
peningkatan kadar enzim transaminase hati, dan hitung trombosit yang rendah (dikenal sebagai sindrom HELLP) dibanding dengan kadar HSP90 serum dari pasien preeklamsi berattanpa disertai dengan sindrom HELLP. Pada pasien preeklamsi berat dengan sindrom HELLP, peningkatan kadar HSP90 yang sangat tinggi menandakan terjadi kerusakan jaringan (hemolisis dan kerusakan hepatoseluler) sekaligus menandakan derajat keparahan penyakitnya. ${ }^{10}$

Simpulan, kadar HSP90 serum preeklamsi berat lebih tinggi dibanding dengan kehamilan normal karena pada preeklamsi berat terjadi stres oksidatif

\section{Daftar Pustaka}

1. Sharma JB, Sharma A, Bahadur A, Vimala N, Satyam A, Mittal S. Oxidative stress markers and antioxidant levels in normal pregnancy and pre-eclampsia. Int J Gynaecol Obstet. 2006;94(1):23-7.

2. Huppertz B. Placental origin of preeclampsia: challenging the current hypothesis. Hypertension. 2008;51(4):970-5.

3. Serrano NC, Díaz LA, Páez MC, Mesa CM, Cifuentes R, Monterrosa A, dkk. Angiotensin converting enzyme I/D polymorphism and preeclampsia risk: evidence of small study bias. Plos Med. 2006:2304-16.

4. Sulistyowati S, Abadi A, Hood J, Soetjipto S. The influence of low HLA-G protein expression on HSP-70 and VCAM-1 profile in preeclampsia. Indonesian J Obstet Gynecol. 2010;34(4):185-90.

5. Valko M, Leibfritz D, Moncol J, Cronin MT, Mazur M, Telser J. Free radicals and antioxidants in normal physiological functions and human disease. Int J Biochem
Cell Biol. 2007;39(1):44-84.

6. Soetrisno. Ekspresi heat shock protein 60, 70, 90 dan kortisol pada persalinan ibu primigravida yang mendapat psikokuratif (disertasi). Surabaya: Universitas Airlangga; 2009.

7. Nasronudin. Efek pernyataan diagnosis terinfeksi HIV/ AIDS terhadap mekanisme apoptosis limfost T-CD4 pada penderita HIV/ AIDS [disertasi]. Surabaya: Universitas Airlangga; 2005.

8. Baird NA, Turnbull DW, Johnson EA. Induction of the heat shock pathway during hypoxia requires regulation of heat shock factor by hypoxia-inducible factor-1. J Biol Chem. 2006;281(50):38675-81.

9. Soti C, Nagy E, Giricz Z, Vígh L, Csermely P, Ferdinandy P. Heat shock proteins as emerging therapeutic targets. Br J Pharmacol. 2005;146(6):769-80.

10. Padmini E, Uthra V, Lavanya S. Effect of HSP70 and 90 in modulation of JNK, ERK expression in preeclamptic placental endothelial cell. Cell Biochem Biophys. 2012;64(3):187-95.

11. Marks L, Zamudio S, Cousins F, Duffie E, Lyall F. Endothelial activation and cell adhesion molecule concentrations in pregnant women living at high altitude. J Soc Gynecol Investig. 2006;13(6):399-403.

12. Lockwood CJ, Oner C, Uz YH, Kayisli UA, Huang SJ, Buchwalder LF, dkk. Matrix metalloproteinase 9 (MMP9) expression in preeclamptic deciduas and MMP9 induction by tumor necrosis factor alpha and interleukin 1 beta in human first trimester decidual cells. Biol Reprod. 2008;78(6): 1064-72.

13. Ekambaram P. HSP70 expression and its role in preeclamptic stress. Indian J Biochem Biophys. 2011;48(4):243-55. 